\title{
Implementasi model numbered head together pada pembelajaran matematika di madrasah ibtidaiyah
}

\author{
Nanda Ihda Rohmatillah H.*, \\ Progam Studi Pendidikan Guru Madrasah Ibtidaiyah, Universitas Muhammadiyah Sidoarjo, \\ Indonesia \\ nandaviv21@gmail.com
}

\begin{abstract}
This research was conducted aiming to influence of the application of the Numbered Head Together Model on student Learning Outcomes in Mathematics Grade IV MI Ma'arif Pamotan. Especially on the circumference of flat shapes material. This type of reserarch used in this research is descriptive quantitative with experimental method. Samples taken form class IV amounting to 30 students. However, due to the outbreak of the Covid-19 virus an did non get permission from parents, researchers were only able to take 17 samples . data collection techniques used were questionnaires, test instrument and documentation. The result of this research used SPSS 25 type showed that the learning of the Numbered Head Together is affect to student learning. This is demonstrated by the results of the analysis of the sig value was acquired by 0,468 with the "T" count $<\mathrm{T}$ table that cause $\mathrm{H} 0$ rejected and Ha received.
\end{abstract}

Keywoards- Numbererd Head Together Model, Learning Outcomes, Mathematich

\section{PENDAHULUAN}

Pendidikan adalah hal yang penting bagi manusia dari kecil hingga dewasa. Pendidikan merupakan usaha mengubah tingkah laku manusia menjadi lebih baik dan juga dapat memperbarui ilmu pengetahuan. Selain itu dengan pendidikan manusia mampu menghargai sesamanya dengan menanamkan sikap toleransi tanpa adanya diskriminasi. Maka dari itu, semua orang dari latar belakang apapun berhak mendapatkan pendidikan.[1] Pendidikan menjadi tantangan bagi manusia yang mengalami perubahan dalam hidupnya sesuai dengan perkembangan IPTEK.[2] Dalam pendidikan terdapat sosok penting yang berpengaruh yang dikenal sebagai guru. Peran guru dalam suatu pembelajaran adalah sebagai penyampai ilmu. Guru dituntut untuk memberikan pembelajaran yang kreatif dan mengembangkannya. Hal ini dikarenakan bahwa keberhasilan guru merupakan tolak ukur bagi keberhasilan siswanya. Seorang guru harus berupaya memberikan memotivasi, dukungan serta bimbingan kepada siswanya. Guru harus memastikan kualitas pembelajaran pada saat siswa beraktivitas.[3]

Tugas guru selain mengajar adalah harus selalu berupaya meningkatkan kualitas pembelajaran yang dilakukan. Peningkatan kualitas pembelajaran tersebut harus dilaksanakan secara sistematis dan terkendali. Salah satu cara yang sistematis dan terkendali itu adalah dengan memanfaatkan model pembelajaran yang kreatif dan tidak monoton untuk digunakan dalam pembelajaran yang bermasalah.[4] Untuk itu perlunya penelitian untuk menguji coba apakah memang dengan mengambil solusi penerapan model pembelajaran yang kreatif dapat membuahkan hasil.

Dalam penelitian ini memfokuskan tentang peningkatan hasil belajar siswa kelas IV di MI Ma'arif Pamotan. Menurut narasumber, hasil belajar Matematika beberapa siswa di kelas IV MI Ma'arif Pamotan masih di bawah KKM yang seharusnya mencapai 75.[5] Faktor dari keterlambatan dalam berfikir siswa, yakni model yang digunakan oleh guru Matematika kelas IV ini menggunakan Model Pembelajaran Langsung. Model tersebut lebih memanfaatkan penerapan penyampaian secara langsung seperti ceramah, diskusi dan tanya jawab. Hal ini memicu adanya siswa yang kurang menguasai kemampuan kognitifnya dalam menyelasaikan tugas pada mata pelajaran Matematika. Dengan demikian hasil belajar yang mereka peroleh tidak mencapai KKM. Model pembelajaran langsung juga menyebabkan siswa menjadi pasif. Pada penelitian ini, peneliti tertarik untuk menggunakan model pembelajaran Numbered Head Toghether. Model pembelajaran Numbered Head Together Ini merupakan strategi pembelajaran yang mengutamakan peserta didiknya untuk bekerjasama dalam 
kelompok. Pembelajaran yang semi permainan ini diharap mampu meningkatkan daya tarik agar siswa mau mempelajari matematika dengan senang dan nyaman.

Model Numbered Head Together termasuk pembelajaran semi permainan. Karena didalam sintak (langkah-langkah) kegiatan pembelajaran tersebut terdapat pemberian nomor di kepala yang diberikan kepada masing-masing siswa.[6] Model tersebut merupakan salah satu model pembelajaran yang lebih mengutamakan adanya suatu kerjasama antar siswa dalam kelompok untuk mencapai tujuan keberhasilan pembelajaran yang diberikan.[7] Model pembelajaran Numbered Head Together penulis pilih untuk mengetahu pengaruhnya dalam hasil belajar matematika kels IV di MI Ma'arif Pamotan. Hasil belajar merupakan suatu pencapaian target pendidikan yang di hasilkan siswa setelah mengikuti proses belajar mengajar.[8] Pada sistem pendidikan nasional menjadikan Benyamin Bloom sebagai rujukan perumusan tujuan pendidikan atau target hasil belajar. Rumusan tersebut dibagi kedalam 3 ranah, yaitu ranah kognitif, afektif, dan ranah psikomotorik. Ranah kognitif mengacu pada intelektual yang dihasilkan.[9] Dari ketiga ranah yang sudah disebutkan, yang paling sering dijadikan patokan nilai di sekolah adalah ranah kognitif. Karena ranah ini berkenan dengan kemampuan siswa dalam menguasai dan memahami dalam proses belajar mengajar

\section{METODE PENELITIAN}

Jenis penelitian yang peneliti gunakan adalah kuantitatif deskriptif dengan menggunakan metode eksperimen. Jumlah populasi dari generalisasi wilayah keseluruhan kelas I-VI dan menjadikan kelas IV yang berjumlahkan 30 siswa sebagai sample peelitian. Namun karena adanya virus covid-19 yang merebah di Indonesia yang mengakibatkan kegiatan belajar mengajar disekolah ditiadakan sementara waktu, dan juga peneliti tidak mendapatkan izin dari bebrapa orangtua siswa maka peneliti hanya mendapatkan sampel dari 17 siswa. Pada saat pengambilan sample penelitian, peneliti menggunakan teknik sample jenis purposive sampling atau teknik sampling non random.[10] Kemudian untuk mengumpulkan data, peneliti menggunakan teknik pengumpulan data berupa observasi membagikan angket, kemudian memberikan instrument test formatif (pre test dan post test) yang berisi 10 soal pilihan ganda dengan pilihan A, B, C, D dan E, dan soal 5 soal essay yang diberikan kepada siswa pada sebelum dan sesudah model Number Head together diterapkan. Kegiatan penelitian ini juga memanfatkan dokumentasi pelengkap.

Setelah semua data terkumpul, peneliti menganalisis data tersebut melalui beberapa tahap untuk mendapatkan hasilnya. Hasil tersebut dapat dilihat dari proses pengujian yaitu : Uji Normalitas, Uji Validitas, Uji Homogentias dan Uji Hipotesis (Uji-T).[11]

\section{HASIL DAN PEMBAHASAN}

Peneliti melakukan penelitian yang bertujuan untuk mengetahui pengaruh model pembelajaran Numbered Head Together tehadap hasil belajar siswa pada matematika kelas IV MI Ma'arif Pamotan. Model pembelajaran Numbered Head Together dipilih peneliti karena strategi pembelajarannya mengutamakan peserta didiknya untuk bekerjasama dalam kelompok. Pembelajaran yang semi permainan ini diharap mampu meningkatkan daya tarik agar siswa mau mempelajari matematika dengan senang dan nyaman.

Peneliti memberikan kesempatan siswa untuk menemukan suatu pengetahuan sendiri dan menyelesaikan sendiri melalui belajar bersama kelompok masing-masing. Guru hanya bertindak sebagai fasilitator dan mediator dengan mengkondisikan siswa secara penuh dalam kegiatan pembelajaran. Dengan menerapkan model pembelajaran ini diharapkan dapat meningkatkan hasil belajar siswa pada matematika. Berdasarkan data penelitian yang sudah dianalisis, hasil penelitian dapat dilihat dari paradigma berikut ini:

Tabel 3.1.1

Rata-rata kelas

\begin{tabular}{lllll}
\hline & Kelas & $\mathrm{N}$ & Mean & $\begin{array}{l}\text { Std. } \\
\text { Error } \\
\text { mean }\end{array}$ \\
\hline Hasil & 1 & 17 & 68.82 & 1.267 \\
& 2 & 17 & 81.71 & 1.121 \\
\hline
\end{tabular}

Berdasarkan tabel output di atas diketahui jumlah dari hasil belajar kelas 1( pre test) adalah sebanyak 17 orang dan jumlah kelas 2 (Post test) juga sebesar 17. Nilai rata-rata hasil belajar siswa kelas 1 
sebesar 68,82 sedangkan kelas 2 sebesar 81.71. Maka secara deskriptif statistik dapat disimpulkan bahwa adanya perbedaan rata-rata hasil belajar kelas 1 dan kelas 2. Kemudian untuk membuktikan perbedaan tersebut siginifikan maka perlu ditafsirkan kembali dengan mengunakan tabel "independent sample test" pada tabel 3.1.2 dan 3.1.3

Tabel 3.1.2

Independent Semple Test

\begin{tabular}{lll}
\hline $\begin{array}{l}\text { Levene's Test } \\
\text { for Equality of } \\
\text { Variances }\end{array}$ & $\mathrm{F}$ & Sig \\
\hline $\begin{array}{l}\text { Equal } \\
\text { Variances }\end{array}$ & 0.540 & 0.468 \\
Assumed & & \\
\hline
\end{tabular}

Dari tabel diatas menunjukkan nilai sig Levene's Test for Equality of Variances hasil belajar siswa pada tabel Equal variances assumed sebesar 0,468 yang berarti > 0,05. Maka dikatakan bahwa varians data kelas pre test dan post test adalah homogen.

Tabel 3.1.3

Independent Samples Test

\begin{tabular}{|c|c|c|c|c|}
\hline \multicolumn{5}{|c|}{ t-test Equality of Means } \\
\hline & $\begin{array}{l}\text { Sig.(2- } \\
\text { tailed) }\end{array}$ & $\begin{array}{l}\text { Mean } \\
\text { Difference }\end{array}$ & $\begin{array}{l}\text { Std.Error } \\
\text { Difference }\end{array}$ & $\begin{array}{l}95 \% \\
\text { Confidence } \\
\text { Interval of the } \\
\text { Difference }\end{array}$ \\
\hline $\begin{array}{l}\text { Equal } \\
\text { variances }\end{array}$ & 0.000 & -12.882 & 1.691 & $\begin{array}{l}\text { Lower } \\
-16.327\end{array}$ \\
\hline $\begin{array}{l}\text { assumed } \\
\text { Equal } \\
\text { variances } \\
\text { not } \\
\text { assumed }\end{array}$ & 0.000 & -12.882 & 1.691 & -16.329 \\
\hline
\end{tabular}

Berdasarkan tabel di atas pada bagian kolom "Equal variances assumed" diketahui besar nilai sig (2tailed) sebesar 0,000 yang berarti < 0,05. Maka dapat disimpulkan H0 ditolak dan Ha di terima. Ada perbedaan rata-rata hasil belajar siswa pada pretest dan post test. selanjutnya dapat dilihat dari tabel “ mean difference "sebesar $-12,882$, nilai tersebut menunjukkan dari rata-rata hasil belajar siswa kelas pre test dengan post test

1. Pengaruh hasil belajar siswa pada matematika kelas IV MI Ma'arif Pamotan.

Berdasarkan hasil data menunjukkan bahwa model pembelajaran Numbered Head Together membawa pengaruh positif dan signifikan terhadap hasil belajar matematika siswa kelas IV MI Ma'arif Pamotan. Hal ini ditunjukkan dari hasil yang diperoleh nilai rata-rata pretest sebesar 68,62, sedangkan rata-rata hasil belajar post test sebesar 81.71 .

Saat pembelajaran peneliti menekankan dan mengajarkan siswa untuk memanfaatkan diskusi kelompok. Dengan menggunakan nomor kepala yang dipakai oleh masing-masing kelompok, siswa merasa senang. Rasa tersebut timbul karena mereka belum pernah mengikuti model pembelajaran yang semi permainan. Seperti yang kita ketahui bahawa anak-anak cenderung senang dengan permainan. Maka model Numbered Head Together ini sangat cocok bagi kelas IV MI Ma'arif Pamotan yang belum merasakan model pembelajaran selain model pembelajaran langsung. Dapat dilihat dari hasil belajar pre-Test siswa yang awalnya nilai di bawah KKM (75), setelah mengikuti pembelajaran mumbered Head together nilai siswa pada soal post test mampu mencapai di atas KKM. Maka dari itu dapat disimpulkan terdapat pengaruh dalam hasil belajar siswa setelah menggunakan pembelajaran Numbered Head Together.

2. Pengaruh Hasil Belajar Matematika kelas IV MI Ma'arif Pamotan dengan menggunakan model Numbered Head Together.

Besar pengaruh hasil belajar siswa antara sebelum diterapkan model pembelajaran Numbered Head Together dan sesudah diterapkan dapat dilihat dari tabel 
Tabel 3.1

Pengaruh Hasil Belajar Menggunakan Model Numbered Head Together

\begin{tabular}{cccc}
\hline Varians & $\mathrm{t}$ & Sig & $\mathrm{df}$ \\
\hline Equal & - & 0.468 & 32 \\
Variances & 7.617 & & \\
Assumed & & & 31.530 \\
Equal & - & & \\
Variances & 7.167 & & \\
not & & & \\
Assumed & & & \\
\hline
\end{tabular}

Berdasarkan tabel 4.10 dapat dilihat bahwa nilai sig diperoleh sebesar 0,468 yang berarti $>0,05$. Dengan t Tabel sebesar 2.03693 dan t hitung -7.617 Maka t hitung < t tabel yang mengakibatkan H0 ditolak dan Ha diterima.

Sehingga dapat ditarik kesimpulan terdapat pengaruh secara signifikan terhadap hasil belajar siswa kelas IV MI Ma'arif Pamotan dengan menggunakan model Numbered Head Together pada saat pembelajaran di kelas IV MI Ma'arif Pamotan. Data ini menunjukkan bahwa terdapat pengaruh yang signifikan pada hasil belajar siswa setelah mendapatkan perlakuan pembelajaran menggunakan model Numbered Head Together (NHT). Cara mengajar seorang guru berpengaruh pada lingkungan belajar. Perlunya guru menyusun strategi yang tepat guna memperkuat pemberian motivasi untuk meningkatkan pembelajaran sekaligus membuktikan bahwa hal tersebut merupakan bentuk dukungan dari sekolah.[12]

\section{KESIMPULAN}

1. Terdapat pengaruh model pembelajaran Numbered Head Together (NHT) terhadap hasil belajar matematika dari kelas IV MI Ma'arif pamotan. Hal tersebut berdasarkan hasil belajar pre-Test siswa yang semula nilainya masih banyak di bawah Kriteria Ketuntasan Minimal (KKM) belajar yaitu sebesar 75. Sedangkan setelah siswa mengikuti pembelajaran Numbered Head Together siswa menjadi aktif dan mampu memahami materi yang disampaikan sehingga nilai siswa pada soal post test mampu mencapai di atas KKM.

2. Besar pengaruh dari hasil data nilai antara pretest dan post test dapat dilihat dari nilai sig yang diperoleh sebesar 0,468. Dengan t Tabel sebesar 2.03693 dan t hitung -7.617. Maka $\mathrm{t}$ hitung < $\mathrm{t}$ tabel yang mengakibatkan H0 ditolak dan Ha diterima. Sehingga dapat ditarik kesimpulan terdapat pengaruh secara signifikan terhadap hasil belajar siswa kelas IV MI Ma'arif Pamotan dengan menggunakan model Numbered Head Together pada saat pembelajaran di kelas IV MI Ma'arif Pamotan.

\section{REFERENSI}

[1] Irgashevich, D. A. (2020). Development of national network (tas-ix). ACADEMICIA: An International Multidisciplinary Research Journal, 10(5), 144-151. Article http://dx.doi.org/10.5958/2249-7137.2020.00254.2

[2] Danim, Sudarwin. 2011. Pengantar Kependidikan. Bandung: Alfabeta.

[3] Pandi, R., \& Nurdyansyah, N. (2017). An Evaluation of Graduate Competency in Elementary School. Atlantis Press. Advances in Social Science, Education and Humanities Research (ASSEHR)

[4] Sardiman. 2004. Interaksi dan Motivasi Belajar Mengajar. Jakarta: PT Raja Grafindo Persada.

[5] Ahmad, Abu dan Joko Tri Prasetya,. 1997. Strategi Belajar Mengajar. Bandung: CV. Pustaka Setia.

[6] Nur istiqomah, Guru Matematika kelas IV MI Ma'arif Pamotan , 10 Desember 2019

[7] Isjoni. 2010. Cooperative Learning Efektivitas Pembelajaran Kelompok. Bandung: Alfabeta

[8] Trianto. 2007. Model - model Pembelajaran Inovatif Berorientasi Konstruktivistik

Kosep Landasan Teoritis - Praktis dan Implementasinya. Jakarta: Pretasi Pustaka.

[9] Mudjiono, Dimyati. 2006. Belajar dan Pembelajaran. Jakarta: Rineka Cipta.

[10] Sudjana, Nana. 2005. Penilain Hasil Proses Belajar Mengajar. Bandung: Remaja 
Rosdakarya.

[11] Sugiyono, 2016. Metode Penelitian (Kuantitatif, Kualitatif, dan R\&D. ( Bandung : Alfabeta CV)

[12] I.Rindaningsih, W.DH \& Yulian F, Desain Lingkungan Belajar yang Mneyenangkan Berbasis Flipped Classroom di Sekolah Dasar. 2019

[13] https://www.spssindonesia.com/ 